\title{
Foraging Activity of Different Pollinators for Seed Setting and Maximizing Seed Yield of Onion
}

\author{
M. M. Kamal ${ }^{1}$, M. M. Akand ${ }^{1}$ \\ I(Scientific officer, Regional spices research centre, Bangladesh Agricultural Research Institute, Bangladesh)
}

\begin{abstract}
The experiment was conducted at the Regional Spices Research Centre, BARI, Gazipur during rabi season, 2012-13and 2013-14 to identify the suitable pollinator attractant crops for increasing the vigilance of pollinators for higher seed settings and thereby increasing seed yield of onion. In 2012-13, four treatments viz., Onion + Fennel (two rows at every 10 rows of onion including border), Onion + Black cumin (two rows at every 10 rows of onion including border), Onion + Coriander (two rows at every 10 rows of onion including border) and Sole onion were compared to achieve the objectives. In 2013-14, the treatment onion + Dill was included and Onion + Black cumin was discarded. One observer was assigned to each replication and observations were synchronized to run between 10.00 to $11.24 \mathrm{hrs}$. Therefore, each observer walked down 28 minutes for each treatment. An insect landing on an open umbel was considered to be a 'visit'. In 2012-13, the highest seed setting was recorded in onion + fennel (69.88\%) which was statistically identical to Onion + coriander $(67.45 \%)$ and Onion + black cumin $(64.15 \%)$ while the highest seed setting was recorded in Onion + Fennel (73.70 \%) which was identical to Onion + Dill (70.50\%) and Onion + Coriander ( $72.37 \%)$ during 2013-14. In 2012-13, the highest seed yield $(865.5 \mathrm{~kg} / \mathrm{ha})$ was obtained from Onion + fennel which was identical to Onion + coriander $(838.1 \mathrm{~kg} / \mathrm{ha}$ ) but differed significantly from other treatments while the highest seed yield $(1165.34 \mathrm{~kg} / \mathrm{ha})$ was recorded from Onion + fennel which was identical to Onion + coriander (1064.59 kg/ha) during 2013-14. In both the years, percent seed setting was lowest in Sole onion $(55.93 \%$ in 2012-13 and 57.73\% in 2013-14). Accordingly, the lowest seed yield was also recorded from Sole onion (623.3 $\mathrm{kg} / \mathrm{ha}$ in 2012-13 and $685.44 \mathrm{~kg} / \mathrm{ha}$ in 2013-14). The best insect pollinator observed was Horse fly for onion crops. The Honey Bee was the second best and Syrphid fly was the third best insect pollinator. The rest of all insects recorded during observation were minor pollinator. Dill and Fennel was the better attractant crop for pollination while coriander acted as intermediate.
\end{abstract}

Keyword: Onion, pollinator, seed yield

\section{Introduction}

Onion is an important spice crop in Bangladesh. The average world production of onion (Bulb) is 15 t/ha and in Bangladesh it is only 7.1 t/ha [1]. The total production of onion in Bangladesh is only 8.89 lakh metric tons [1] as against the estimated demand of 15.75 lakh metric tons [2]. It is possible to meet up the demand by increasing per unit yield through supplying quality seeds or by bringing more area under onion cultivation. Pollinator also plays a vital role for quality seed production and increased seed yield. Now a day the vigilance of pollinators is not enough in onion field for more fertilization as well as for quality seed production. In northern region, the seed production is badly hampered due lack of sufficient vigilance of pollinators. Many of the pollinators we depend on are under threat, and some crops are showing decreases in production due to a shortage of pollinators. Acute deficit of natural pollinators is one of the main reasons of low onion seed yields [3]. Farmers now have to import/ raise pollinators to ensure good production of their crops [4]. Onion is cross pollinated in nature and bee's, flies and other insects helps in pollination. Single umbel flowers of the onion inflorescence are not capable of self-pollination. The pollen must come from another flower of the same or different plant for its pollination [5]. The decrease of natural pollinators on onion seed production field causes a serious problem for quality seed production in Bangladesh.

It is also possible in some situation to encourage the vigilance of different flies, like honey bee, house fly, blow fly, bumblebees, dipterans and butterflies population by distributing suitable pollinator attractants like border crop (Fennel, Dill \& Black cumin), fruit juice (mango, jackfruit etc) or dried fish surrounding/within the flowering crop [6]. Coriander, Fennel and black cumin may be good attractant for increasing the vigilance of pollinators because their flower colour and smell is attractive, which encourage the vigilance of the pollinators. There is enough scope to use these crops as boarder or intercrop for increasing the vigilance of different pollinators. In Bangladesh, little work has been made in this regard. With this view, the present study has been aimed to identify pollinator insects of onion and their vigilance on onion for higher seed yield of onion through suitable attractant crop(s) for increasing the vigilance of pollinators. 


\section{Materials And Methods}

The experiment was conducted at the Regional Spices Research Centre, Bangladesh Agricultural Research Institute (BARI), Gazipur during rabi season, 2012-13 and 2013-14 to identify suitable attractant crops for increasing the vigilance of pollinators for higher seed setting and thereby increasing seed yield of onion. The land was medium high and the soil was clay loam in texture. The experiment was laid out in randomized complete block design with three dispersed replications. The distance among replications varied from $500 \mathrm{~m}$ to $600 \mathrm{~m}$. In 2012-13, four treatments viz., Onion + Fennel (two rows at every 10 rows of onion including border), Onion + Black cumin (two rows at every 10 rows of onion including border), Onion + Coriander (two rows at every 10 rows of onion including border) and Sole onion were compared to achieve the objectives. In 2013-14, the treatment Onion + Black cumin was discarded and onion + Dill was included along with other treatments. The unit plot size was $11.8 \times 8 \mathrm{~m}^{2}$ in 2012-2013 and 7.2 $\times 6 \mathrm{~m}^{2}$ in 2013-14.In each plot, BARI Piaz 4 was planted maintaining $20 \mathrm{~cm} \times 15 \mathrm{~cm}$ spacing. As per treatments, the boarder crop was planted in paired rows, maintaining $30 \mathrm{~cm} \times 15 \mathrm{~cm}, 30 \mathrm{~cm} \times 15 \mathrm{~cm}, 20 \mathrm{~cm} \times 15 \mathrm{~cm}$ and $30 \mathrm{~cm} \times 15 \mathrm{~cm}$ spacing for Fennel (Advance line), Dill (Advance line), Black cumin (BARI Kalizira 1) and Coriander (BARI coriander 1), respectively. The crop (onion) was planted through 13-14 November 2012 and 13-15 in November 2013. The border crop was planted few days later than that of onion planting. In 2012-13, Fennel was sown on the day of onion planting, Black cumin was sown on 16 days later than onion planting and Coriander was sown on 15 days later than onion planting. In 2013-14, Fennel and Dill was planted on the day of onion planting, and Coriander was sown on 4 December (20days later than onion planting). In addition to $5 \mathrm{t} / \mathrm{ha}$ of cow dung, the crop was fertilized with $\mathrm{N}_{145} \mathrm{P}_{83} \mathrm{~K}_{84} \mathrm{~S}_{20} \mathrm{Zn}_{3} \mathrm{~B}_{2} \mathrm{~kg} / \mathrm{ha}$. The entire amount of cow dung P, S, Zn, B, 1/4N and 1/3 K was applied during final land preparation. The rest $\mathrm{N}$ was applied in three equal splits at 40,60 and 80 days after planting (DAP) in both the years.. The rest $\mathrm{K}$ was applied in two equal splits at 40 and 60 DAP. No additional fertilizer was used for boarder crops. To control purple blotch disease, the crop was sprayed with 'Rovral' @ 2g /L of water at 40, 50, 60 and 70 DAP in both the years. Similarly, to control thrips, 'Gain' @ $0.25 \mathrm{ml} / \mathrm{L}$ of water was sprayed at $35,45,55$ and 65 DAP. The spray remained stopped after initiation of first blooming. One observer was assigned to each replication and observations were synchronized to run through 10.00 to 11.24 . Therefore, each observer walked down 28 minutes for each treatment. An insect landing on an open umbel was considered to be a 'visit'. The observation started from 6 February to 3 April in both the years. The observers rotated to different replications in alternate day in a cyclic order. A nearly similar observation technique was also used by [7]. Starting and finishing of counting was done at the same time. The visit was counted by eye estimation. Data on plant height, scape height, number of umbel per plant, diameter of umbel, number of flowers per umbel, number of flowers setting seeds per umbel, percent seed settings, 1000-seed weight, seed yield, types of pollinator and number of vigilance were recorded. Except vigilance, all other data were analyzed and mean separation was done by DMRT following MSTAT software.

\subsection{Vigilance of pollinator insect 3.1.1 Vigilance on onion}

Interaction between flowering plants and their pollinators are usually considered mutualisms [8]. Plants provide rewards (nectar and/or pollen) to their visitors, and the pollinators benefit the plants by carrying pollen and effecting pollination [9].

In the present study, Honey bee, Syrphid fly and Horse fly were the major insect pollinators while Blow fly, House fly, Bumble bee, Paper wasp, Yellow Jacket, Butter fly etc were the minor pollinators of onion. [10] reported that from tens to hundreds of different species of insect have been identified visiting blooming onion umbels, the number of species depending on the locality. [11] reported that the community of pollinators was mainly composed of two bee species i.e. A. dorsataand A. floreaand eight fly species i.e., Episyrphusbalteatus, Eupeodescorollae., Sphaerophoriascripta $(\mathrm{L}), \quad$ Mesembriusbengalensis, Eristalinusaeneus(all Syrphidae), Muscadomestica(Muscidae), Calliphoridae sp. and Sarcophagasp. (Sarcophagidae).

\subsubsection{Horse fly (Tabanus spp.)}

Insects in the order Diptera, family Tabanidae, are commonly called horse flies. They are also important pollinators of flowers, especially in South Africa. Adult horse flies feed on nectar and sometimes pollen [12]. It was observed as a fast moving fly during counting. It moves quickly from one flower to another, however, it stays more times on single florets. It scared more from the observer during counting which enhanced its quick moving activities. Horsefly showed its preeminence as a major visitor for onion pollination. The result indicated that initial visit of this insect to onion was poor and gradually increased with the advancement of blooming stage (from 10 February - 26 March). In 2012-13, the peak visit of Horsefly was recorded on onion + 
coriander at 25 February (444 visits), 12 March in onion + black cumin (358 visits), 15 March in onion + fennel (595 visits) and 10 March in sole onion (155 visits).

In 2013-14, the peak visit was recorded on 10 March (545 visits) in onion + Dill, 13 March (514 visits) in onion +fennel, 6 March (421 visits) in onion + coriander and 12 March in sole onion (152 visits). The visit of horse fly gradually increased to its peak value and thereafter, declined at the end of the blowing period (Fig. $1 \& 2)$. Actually, the blooming period of onion was recorded from 10 February to 26 March 2013. However, the full blooming period lasts for 33 days (18 February to 20 March 2013). About 95\% flowers opened on 15 March.

The peak visit of Horse fly varied from 10-15 march in different treatments with the exception that its peak visit in Onion + Coriander treatment was on 25 February in 2012-13. This might be due to the fact that about $70 \%$ flowers of coriander opened on 25 February, thereafter, flower opening completed within few days and accordingly the later part of onion was without coriander flower in 2012-13. In 2013-14, the peak visits of horse fly in onion + coriander treatment was on 6 March, during that time flower opening in coriander was $85 \%$ and corresponding flower opening in onion was $80 \%$.Similarly, the peak visit of horse fly on onion in onion + black cumin treatment was on 12 March in 2012-13. During that time flower opening in Black cumin was $90 \%$ and corresponding flower opening in onion was $75 \%$.

In 2012-13, the peak visit of horse fly on onion in onion + fennel treatment was on 15 March during that time flower opening in fennel was $80 \%$ and the corresponding flower opening in onion was $85 \%$. In 201314, the peak visit of Horse fly in onion + Dill treatment was on 10 March during that time flower opening in onion was $82 \%$ and the corresponding flower opening in Dill was about $75 \%$.
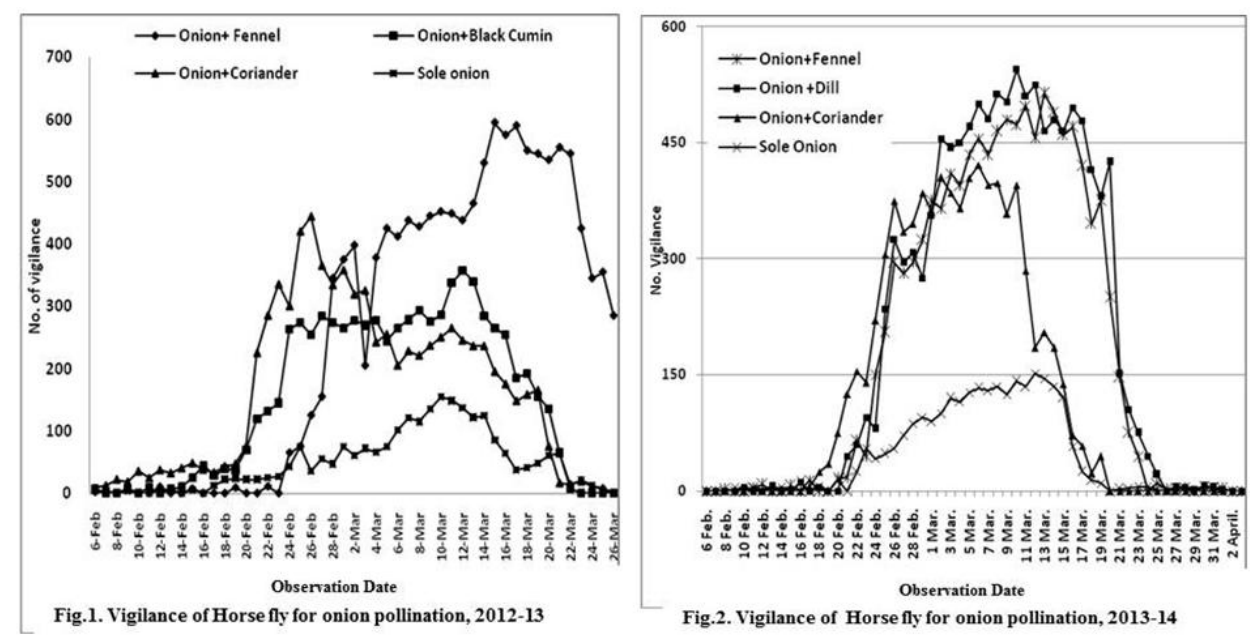

\subsubsection{Honey bee (Apis spp.)}

Honey bee (Apis spp.) had marked influence as next to horse flyin onion pollination. It belongs to the family Apidae of the order Hymenoptera. It was a moderately fast moving pollinating insect observed during counting. It scared less from the observer during counting. It may not consume much time on a single florets rather it moves softly and quickly from florets to florets. Hence, it might be assumed that it pollinates more florets in unit time compared to Horse fly. There was a numeric increase in total number of bee visitors and thereafter, declined during the end of the blooming stage. The results are in agreement with the findings of [7] in water melon. In 2012-13, the peak visit of Honey bee was recorded on 15 March (135), 12 march (104 visits ), 21 February (120 visits) and 7 march ( 72 visit) in onion + fennel, onion+ black cumin, onion + coriander and sole onion treatments, respectively (Fig. 3). Similarly in 2013-14, the peak visit of honey bee was recorded on 7 March (194 visits), 12 March (185 visits), 4 March (168 visits) and 13 March (92 visit) in onion+ Dill, onion + fennel, onion + coriander and sole onion treatments, respectively (Fig. 4). The result indicated that vigilance of honey bee was more in 2013-14 compared to 2012-13. Honey bee population declined due to parasites, pest, diseases, higher frequency of pesticide use and many other factors in Bangladesh. Similar population declined also observed in North America [7]. Therefore, use of these attractant crops might have significant role in onion pollination.[13] reported much higher seed yield of onion on uncovered plots than in isolation cages with the honeybee. They also pointed out that 1000 seed, germination capacity and energy are higher when onion flowers are pollinated by honey bees. In cases when there is lack or inadequate wild bees, the honeybee becomes the indispensable insect in the onion commercial seed production [3]. 

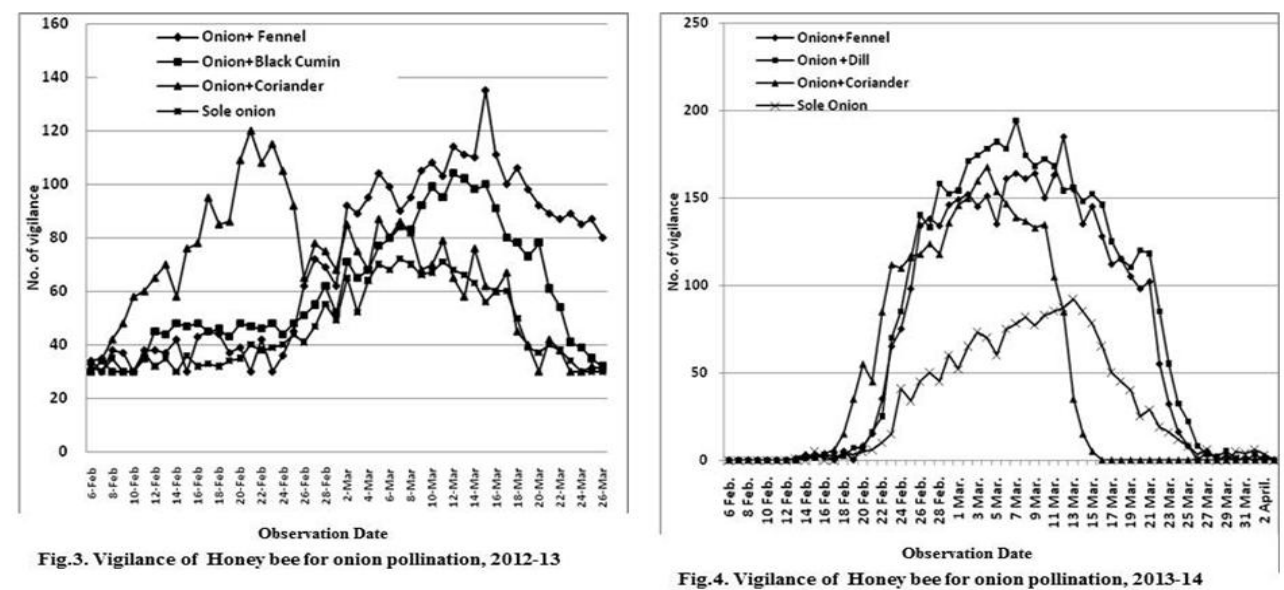

\subsubsection{Syrphid fly (Helophilus spp.)}

Several types of syrphid flies are found in our country. It belongs to the family Syrphidae of the order Diptera. We got Helophilus type of Syrphid flies in our study. In 2012-13, the peak visit was recorded on 14 march (30 visits), 10 March (22 visits), 26 February (25 visits) and 11 March (16 visits), in onion + fennel, onion + black cumin, onion + coriander and sole onion, respectively (Fig. 5).In 2013-14, the peak visit was recorded on 11 march (48 visits), 13 March (44 visits), 5 March (40 visits) and 7 March (32 visits), in onion + Dill, onion + fennel, onion + coriander and sole onion, respectively (Fig. 6). Like honey bee, the vigilance of syrphid fly was more in 2011-12 compared to 2010-11. The characteristic feature of this insect is that it can be able to fly stand still in one place. It scared much more than that of other insect observed during counting. It likes to move lower catena of the vegetation and when opportunity comes they flies on flower. Dipterans from the syrphid (Syrphidae) family take part in the process of onion pollination [14]. The spectrum of pollinator abundance among the dipteran species, $72 \%$ was composed of syrphid flies and $28 \%$ of nonsyrphids[11].Eupeodescorollae (Syrphidae) exhibited the most efficient foraging behavior by visiting $17.14 \pm 1.38$ flowers in $147.5 \pm 8.14$ seconds on an umbel [11].

\subsubsection{Blow fly (Phormiaregina)}

Blow flies are fairly large, metallic green, gray, blue or black flies found throughout the world. Common species include the green bottle flies (Lucilia spp.), black blow fly (Phormiaregina), and various Calliphora species. In our present study, we got only one, the black blow flies (Phormiaregina), which belongs to the family Calliphoridae of the order Diptera. In 2012-13, the peak visit of blow fly on onion was recorded on 14 march (17 visit), 11 march (12 visits), 28 February (12 visits) and 7 March (9 visits) in onion + fennel, onion + black cumin, onion + coriander and sole onion treatments, respectively (Fig. 7). In 2013-14, the peak visit of blow fly on onion was recorded on 16 march (17 visit), 18 march (15 visits), 9 March (11 visits) and 11 March (8 visit) in onion + Dill, onion + fennel, onion + coriander and sole onion treatments, respectively (Fig. 8).To some extent it also consumed more time on single florets, so it was assumed that it could be able to visit fewer number of flowers. The spectrum of pollinator abundance among the dipteran species, $72 \%$ was composed of syrphid flies and $28 \%$ of non-syrphidsi.e. M. domestica, Calliphoridae sp. and Sarcophagasp.[11]. Effect of pollination by blowflies (Calliphora and Lucilia spp.) and honeybees (Apismellifera) on seed yield of onion was studied by [15] and found that fly pollination gave significantly higher yields than bee pollination in two experiment but in the third, bee pollination gave slightly more seed yield.
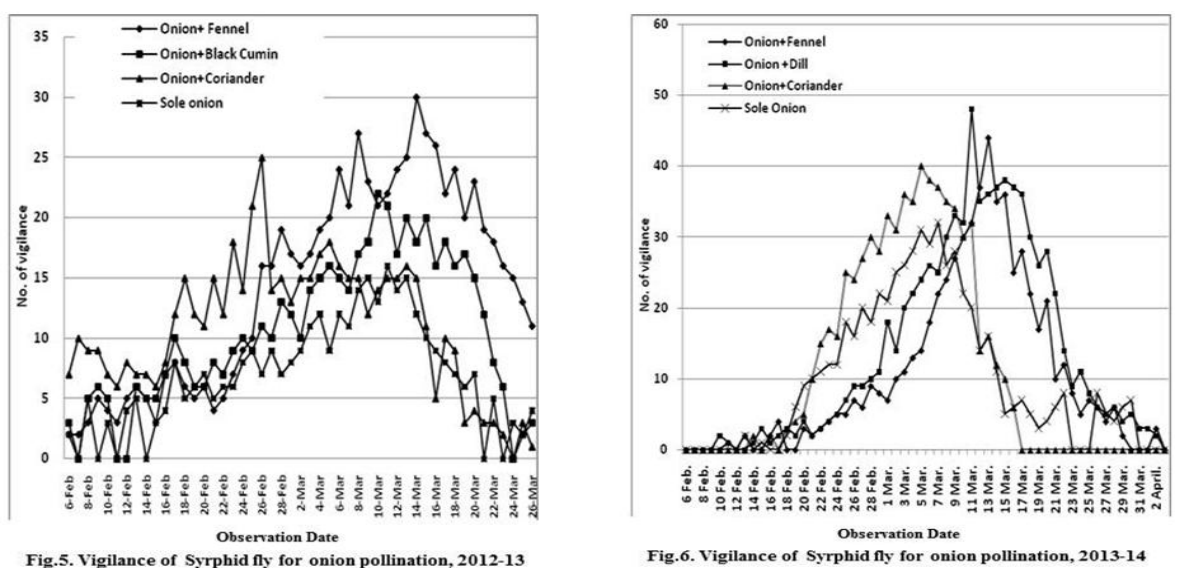

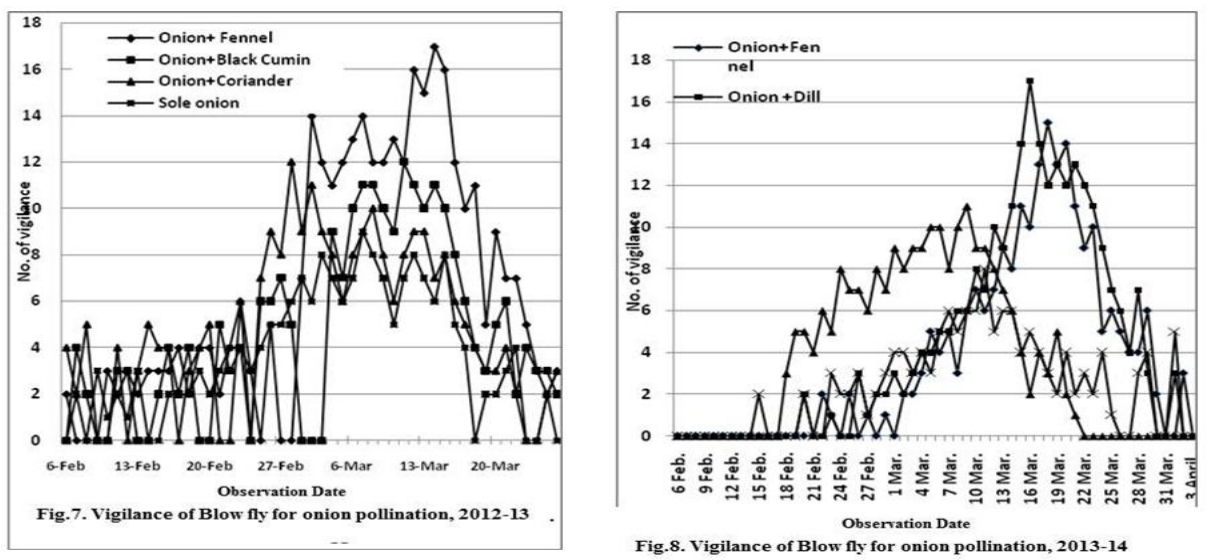

\subsubsection{House fly (Musca domestica)}

The common species is Musca domestica. It is most common amongst all flies in the world. It is said that houseflies account for nine out of every ten flies that inhabit the homes. In our present study, we got Musca domestica L. types of house fly which belongs to the family Muscidae of the order Diptera. It is also one of the minor insects visited onion flowers. They take rest on stem or leaf of the crops and time to time visited onion flower. In 2012-13, the peak visit was recorded on 14 March (16 visits), 10 March (13 visits), 25 February (14 visits) and 13 March (8 visits) in onion+ fennel, onion + black cumin, onion + coriander and sole onion treatments, respectively (Fig. 9). Similarly, in 2013-14, the peak visit was recorded on 14 March ( 17 visits), 14 March ( 14 visits), 10March (13 visits) and 15 March (9 visits) in onion + Dill, onion+ fennel, onion + coriander and sole onion treatments, respectively (Fig. 10) The spectrum of pollinator abundance among the dipteran species, $72 \%$ were composed of syrphid flies and $28 \%$ of non-syrphidsi.e. M. domestica, Calliphoridae sp. and Sarcophaga sp. [11].

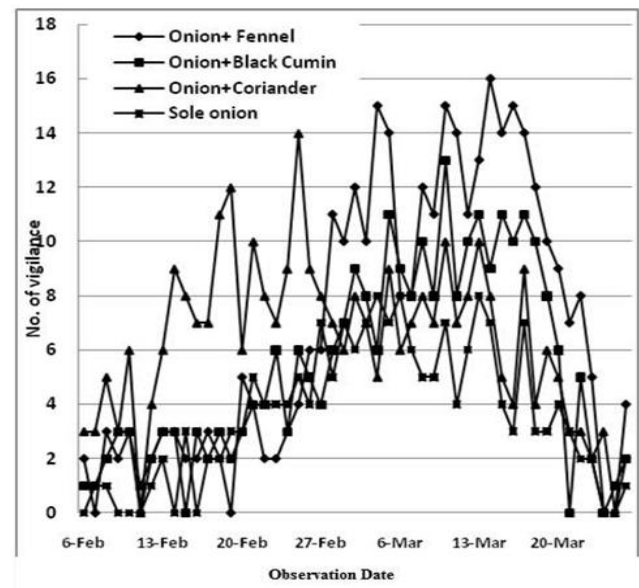

Fig.9. Vigilance of House fy for onion pollination, 2012-13

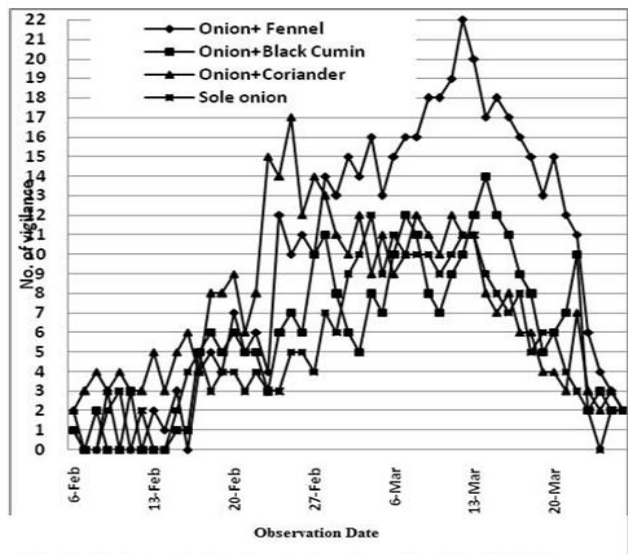

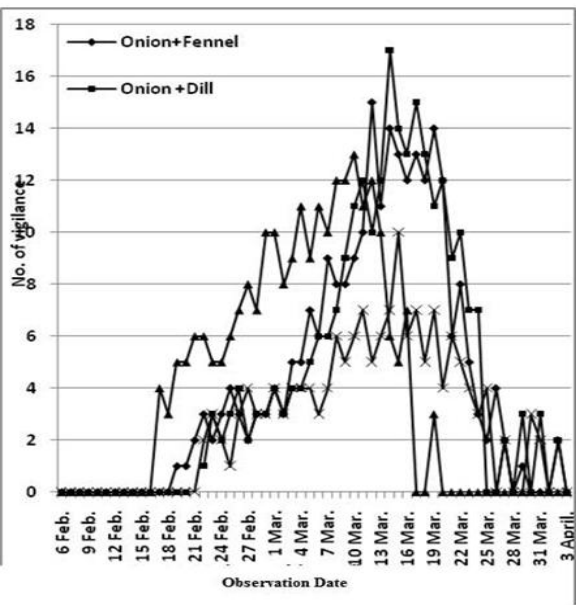

Fig.10. Vigilance of House fy for onion pollination, 2013-14

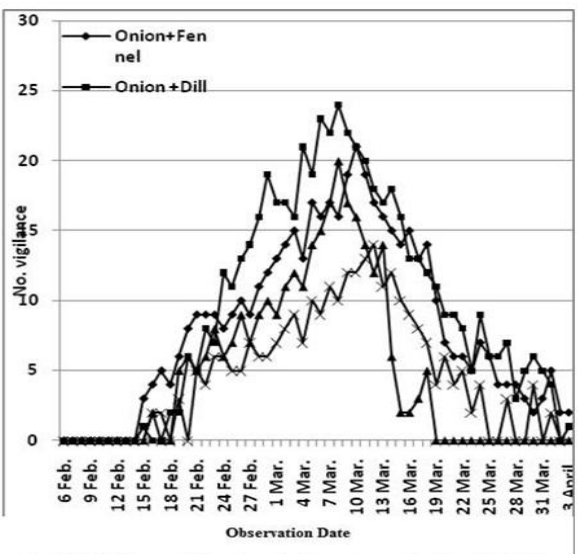

Fig.12. Vigilance of other insects for onion pollination, 2013-14 

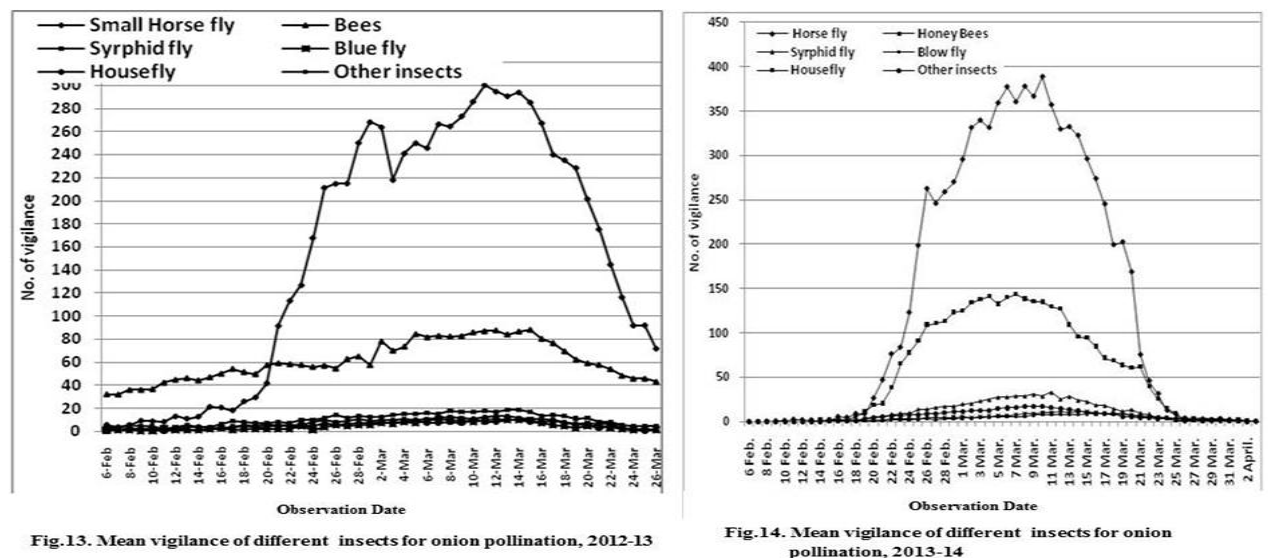

\subsubsection{Other insects}

Other insect that visited onion crops for pollination was Bumble bees, Paper wasp, Yellow jacket (Vespula spp.), Butter flies etc considered as minor insect pollinator in onion (Fig. 11\&12). Apart from honey bees, onion flowers are also visited by bumblebees, dipterans and butterflies [16, 17]. Bumble bees are efficient pollinators of crops wherever they are sufficiently abundant and particularly important in weather too cool for honey bees. They are better pollinators than honey bees of solanaceous and ericaceous crops. The use of bumble bees (BombusterrestrisL.) for the managed pollination of aubergine, blueberry, melon, raspberry, red currant, strawberry, sweet pepper, tomato, carrot, cauliflower and brussels sprout, almond, apple, blueberry, cherry, cranberry, peach, pear and plum is being assessed by [18].

The best insect pollinator was Horse fly for onion crops (Fig. 13\&14). However, Bee was the second best and Syrphid fly was the third best insect pollinator. The rest of all insects recorded during observation were minor pollinator. In general and irrespective of insect, the vigilance was poor at the early stage of blooming and attained its peak value at full blooming stage, thereafter, declined at the end of the blooming stage. The poor visit of pollinator during early stage of blooming might be due to opening of less number of onion flowers and cool temperature prevailed in the crop field which did not favour the insect pollinator.

\subsection{Vigilance on Onion vs. attractant crops}

In 2012-13, the peak visit of Horse fly in attractant crops was on 15 March (387 visits, Fig.27) compared to onion on 11 March (300 visits, Fig. 13). Similarly, for honey bee, the peak visit on attractant crops was on 8 March (104 visits, Fig. 27) compared to onion on 15 March (88 visits, Fig.13) while the peak visit of syrphid fly in attractant crops was on 12 March (23 visits, Fig. 27) compared to onion on 8 March (18 visits, Fig. 13).

In 2013-14, the peak visit of Horse fly in attractant crops was on 17 March (566 visits, Fig. 28) compared to onion on 10 March (388 visits, Fig 14.). Similarly, for honey bee, the peak visit on attractant crops was on 11 March (145 visits, Fig. 28) compared to onion on 7 March (144 visits, Fig. 14) while the peak visit of syrphid fly in attractant crops was on 20 March (38 visits, Fig. 28) compared to onion on 11 March (33 visits, Fig. 14).

Similarly for other insects, the peak visits on attractant crops were always higher than that of onion. In both the years, the result was therefore, indicated that the visit of all insects was more in attractant crops compared to onion (Fig. 13, 14, 27 \& 28).

\subsection{Yield and other parameters}

The yield and yield contributing characters of onion as affected by different treatments are presented in Table 1\&2. In both years, the number of seeds setting per umbel, percent seed settings, and seed yield were significantly affected by different treatments while other parameters were not significant.

Different attractants had no significant effects on plant height of onion. However, in 2012-13, the tallest plant was recorded from Sole onion $(93.13 \mathrm{~cm})$, which was followed by Onion + Fennel $(92.20 \mathrm{~cm})$, and Onion + Coriander $(91.27 \mathrm{~cm})$ (Table 1). Similarly, the tallest plant was recorded from onion + Dill $(105.27 \mathrm{~cm})$ which was followed by Onion + Fennel $(103.55 \mathrm{~cm})$, Sole onion $(99.00 \mathrm{~cm})$ and , Onion + Coriander $(98.67 \mathrm{~cm})$ in 2013-14 (Table 2).

The scape height of onion followed similar trend of results as in plant height (Table 1\&2). In 2012-13, the longest scape was recorded in Onion + Fennel $(89.71 \mathrm{~cm})$ which was followed by Onion + Coriander $(88.59$ $\mathrm{cm})$ and sole onion $(87.50 \mathrm{~cm})$ while the longest scape was recorded from onion + Dill $(101.72 \mathrm{~cm})$ which was 
followed by Onion + Fennel $(100.15 \mathrm{~cm})$, Sole onion $(95.67 \mathrm{~cm})$ and , Onion + Coriander $(95.33 \mathrm{~cm})$ during 2012-13.

Different attractants had no significant effects on the number of umbels per plant, however, the highest number of umbels per plant was counted in Onion + Black cumin treatment (3.66/plant) in 2012-13 while it was highest in Onion + Fennel (3.80/plant) during 2013-14.

No significant influence of attractants was observed on the diameter of umbel, however, the highest diameter was measured in Onion + Fennel followed by Onion + Black cumin $(7.66 \mathrm{~cm})$ and sole onion $(7.71$ $\mathrm{cm})$ during 2012-13 while it was highest in Onion + Coriander $(7.78 \mathrm{~cm})$ during 2013-14.

In both the years, different attractant had no significant effect on the number of flowers per umbel, however, the highest number of flowers were recorded in sole onion (528/umbel) which was followed by Onion + Fennel (523.3/umbel) and onion + coriander (518.3/umbel) during 2012-13 but it was highest in Onion + Fennel (546.3/umbel) during 2013-14.

The influence of attractants was found non-significant on the 1000-grain weight of onion. The heaviest 1000-grain was recorded in Onion + Fennel (3.04 g) in 2012-13 while it was heaviest in Onion + Coriander (3.11g) in 2013-14.

Different attractants had marked impact on the number of seed settings per umbel (Table $1 \& 2$ ). In 2012-13, the highest number of seed setting was recorded in Onion + Fennel (363.7/umbel) which was identical to Onion + Coriander (346.7/umbel) while the highest number of seed setting was recorded in Onion + Fennel (402.3/umbel) which was identical to Onion + Dill (378.58/umbel) and Onion + Coriander (382.97/umbel) during 2013-14. In both the years, the lowest seed setting was recorded in sole onion (295.3/umbel in 2012-13 and 307.7/umbel in 2013-14). In 2012-13, the highest seed setting in Onion + Fennel might be due the fact that fennel attracts more pollinator insects to onion which positively pollinate more flowers for seed settings. Earlier, it was also mentioned that fennel was one of the best attractant crop for pollination. The identical results in Onion + Coriander might be due to the same reason where Coriander was the second best attractant for crop pollination. In 2013-14, more pollinator was attracted by the Dill followed Fennel but seed settings was slightly higher in Fennel.

Different attractants exhibit significant influence on percent seed settings in onion (Table $1 \& 2$ ). In 2012-13, the highest seed setting was recorded in onion + Fennel $(69.88 \%)$ which was identical to Onion + Coriander $(67.45 \%)$ and Onion + Black cumin $(64.15 \%)$ while the highest seed setting was recorded in Onion + Fennel $(73.70 \%)$ which was identical to Onion + Coriander $(72.37 \%)$ and Onion + Dill $(70.50 \%)$ during 2013-14. The percent seed setting was found highest in 2013-14 compared to 2012-13. The percent seed setting was lowest in Sole onion (55.93\% in 2012-13 and 57.73\% in 2013-14). The lowest seed settings in sole onion might be due to absence of attractants crop in the onion field. Non-availability of pollinators during the flowering period of onion causes only $17 \%$ fruit setting and free availability of pollinators increased fruiting up to $73 \%$ [19]. [20] reported 70- 72\% seed settings in summer onion in Bangladesh. Similarly, [21] claimed 60-65 $\%$ seed settings in onion on 30 October planting.

Different attractants crop demonstrated marked influence on the seed yield of onion. In 2012-13, the highest seed yield $(865.5 \mathrm{~kg} / \mathrm{ha})$ was obtained from Onion + Fennel which was identical to Onion + Coriander $(838.1 \mathrm{~kg} / \mathrm{ha})$ but differed significantly from other treatments. Similarly, the highest seed yield $(1165.34 \mathrm{~kg} / \mathrm{ha})$ was obtained from Onion + Fennel which was identical to Onion + Coriander (1064.59kg/ha) during 2013-14. The lowest seed yield was recorded from Sole onion $(623.3 \mathrm{~kg} / \mathrm{ha}$ in $2010-11$ and $685.44 \mathrm{~kg} / \mathrm{ha}$ in $2013-14)$.

In addition to this, about $1.37,1.45$ and 0.53 t/ha of Fennel, Coriander and Black cumin was harvested as an inter crop seed yield in 2012-13 while it was 1.05, 1.15 and $0.58 \mathrm{t} / \mathrm{ha}$ of fennel, coriander and Dill during 2013-14. In 2012-13, the highest seed yield in Onion + fennel might be due to the fact that fennel attracts more insects pollinator (Fig. 13 \&27) which positively pollinate more flowers for seed settings. Again, the number visits of all insect were more in fennel and corresponding visit in onion is also more. Pollinator visits from one plant to another plant and create pollination. Therefore, more visits might have a chance to cause more pollination. The consequence of which resulted in more seed settings and seed yield of onion in Onion + Fennel treatments.

In 2013-14, Dill attracted more pollinator followed by fennel but seed settings was slightly higher in fennel which resulted higher seed yield in fennel. Further, seed settings in Dill were slightly lower compared to coriander so the yield was slightly lower. This was because part of the onion plot along the edge was covered by the over growth of Dill which hampered growth and pollination in that part, the consequence of which reduced seed yield. Pollinator goes to a flower seeking nectar and, in the process, pollen from the male part of the flower sticks to the pollinator's legs or other parts of its body. When it flies on to another flower of the same type, the pollen is deposited on the female part of the plant. This allows the plant to reproduce by creating seeds and fruit [4]. The identical results in Onion + Coriander might be due to the same reason where Coriander was the second best attractant for crop pollination. Without attractant crops in sole onion might be the reason for lowest yield. In case of Black cumin, in Onion +Black cumin treatment more pollinator insect visited compared 
to Sole onion. Again, the vigilance of pollinator on onion was lower compared to Onion + Fennel and Onion + Coriander because of lower height of Black cumin. Pollinator visited on lower height Black cumin did not prefer to visit on longer height onion in Onion + Black cumin treatments. As result pollination was poor consequently the yield was lower.

\section{Conclusion}

In review of the result of the study, it can be concluded that for higher seed setting and obtaining higher seed yield of onion, Pollinator attractant crop like Fennel and/or Coriander can be planted in a sequence of two rows for every alternate 10 rows of onion including border. Height of the pollinator attractant crops if possible should be nearly same as that of onion. Planting of attractant crops should be synchronize in such a way so that flowering period of the attractant crops should be at least at the same time of onion. Fennel should be planted at the time of onion planting. Coriander should be planted 20-22 days after onion planting. Dill should be planted on the day of onion planting but further study may be needed for Dill regarding its performance for onion seed settings.

TABLE-1. Effect of different crops as pollinator attractant on seed yield and yield contributing characters of onion during Rabi season, 2012-2013.

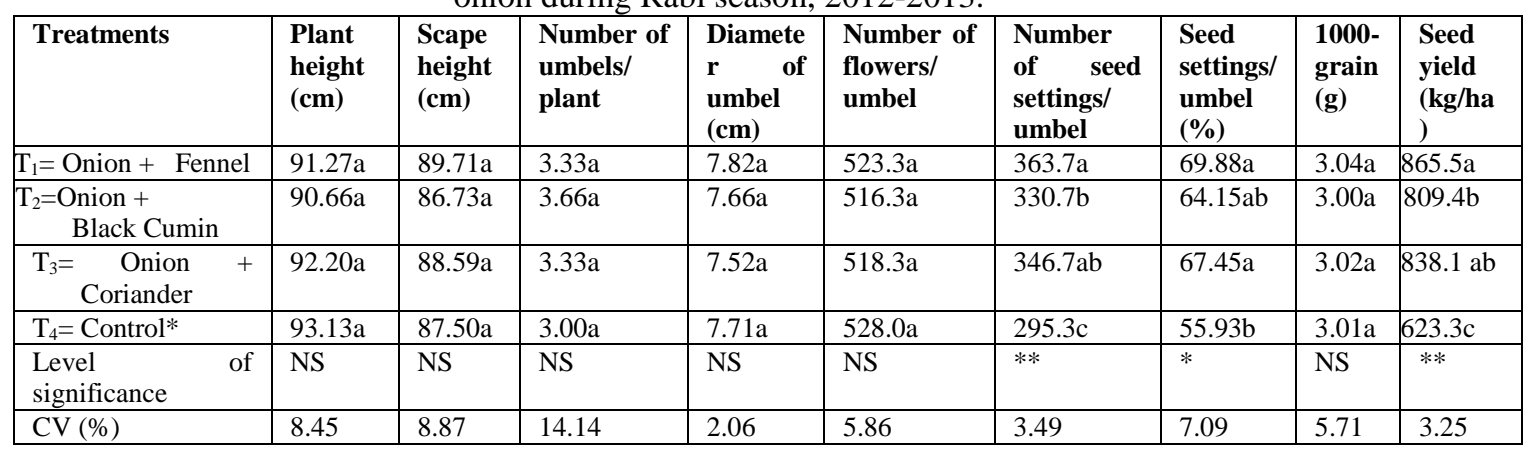

In a column, means followed by the same letters did not differ significantly at $5 \%$ levels of probability *Control (without attractants crop), Mean plant population: $\mathrm{T}_{1=243500 / \mathrm{ha}}, \mathrm{T}_{2=242050}, \mathrm{~T}_{3=243000}, \mathrm{~T}_{4=245250}$

TABLE-2 Effect of different crops as pollinator attractant on seed yield and yield contributing characters of onion during Rabi season, 2013-2014.

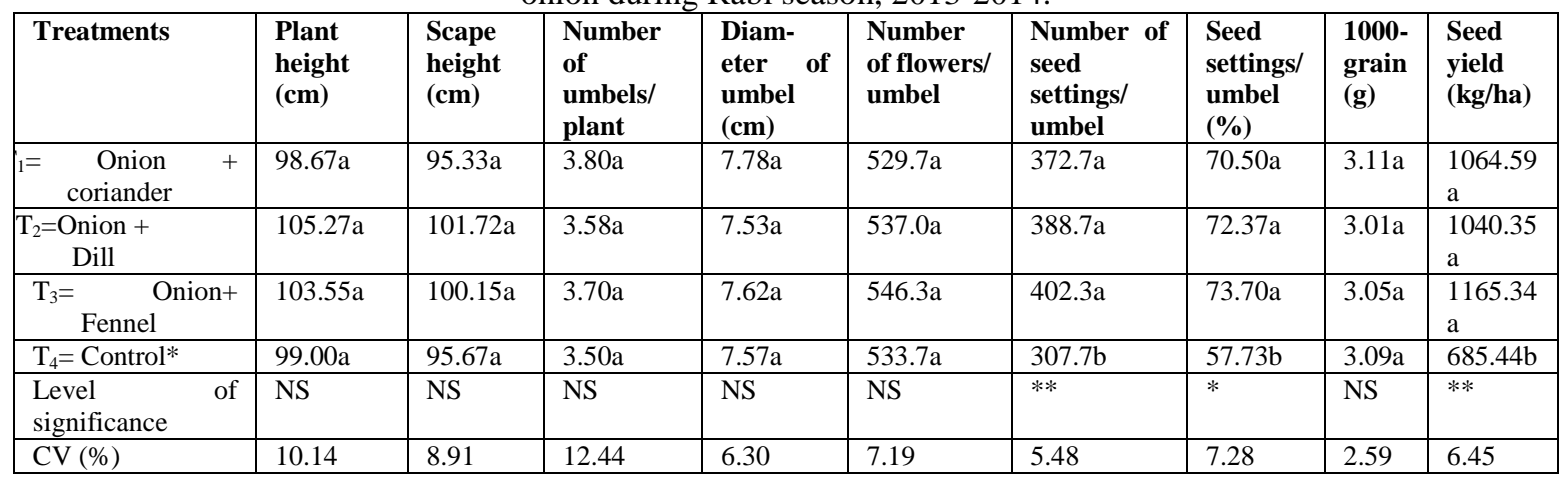

In a column, means followed by the same letters did not differ significantly at $5 \%$ levels of probability *Control (without attractants crop), Mean plant population: $\mathrm{T}_{1=243200 / h a}, \mathrm{~T}_{2=241850}, \mathrm{~T}_{3=242500}, \mathrm{~T}_{4=244325}$

\section{References}

[1] BBS (Bangladesh Bureau of Statistics), Year Book of Agricultural Statistics of Bangladesh, Bureau of statistics, Ministry of planning. Govt. of Bangladesh. 2008,106.

[2] BARI (Bangladesh Agricultural Research Institute).2010. MashlaUtpadonProjucti Manual. (In Bangla), Spices Research Centre, Shibgonj, Bogra, Bangladesh, 2.

[3] Witter S. andB. Blochtein, Effect of pollination by bees and other insects on the production of onion seeds. Pesq. gropec. bras.,38(12),2003, 1399-1407.

[4] CWF (Canadian Wildlife Federation), Wildabout gardening. Gardening for Wildlife. Electronic publication at http://www. cwffcf.org/en/what-we-do/habitat/contact. (Canadian Wildlife Federation, 350 Michael Cowpland Drive, Kanata, ON K2M2W1.Canada, 2008) 
[5] Wilkaniec Z.Giejdasz K. and G. Prószyñski,Effect of pollination of onion seeds under isolation by the red mason bee (OsmiarufaL.) (Apoidea, Megachilidae) on the setting and quality of obtained seeds.Journal of Apicultural Science.Vol. 48(2),2004,35-41.

[6] Currah, L. and F. J. Proctor. Onions in Tropical Regions.( Bulletin 35, Natural Resources Institute, Chatham, Kent, UK, 1990).

[7] Ellis, A., and K.S. Delaplane, An evaluation of Fruit-Boost ${ }^{\mathrm{TM}}$ as an aid for honey bee pollination under conditions of competing bloom. Journal of Agricultural Research and Bee World. 48 (1), 2009, 15-18.

[8] Cushman, J.H., and A.J. Beattie, Mutualisms: Assessing the benefits to host and visitors. Trends Ecol. Evol. 6, 1991. 193-195.

[9] Lasso, E., and M.E. Naranjo, Effect of Pollinators and nectar robbers on nectar production and pollen deposition in Haeliapatens (Rubiaceae). Biotropica. 35(1),2003, 57-66.

[10] L. Currah, Pollination biology. (In: Rabinowitch, H.D. and Brewster, J. L. (eds). Onion and Allied Crops Vol. 1. CRC Press. Boca Raton, Florida,1990,135-149)

[11] Sajjad, A., Saeed, S and A. Masood,Pollinator Community of Onion (Allium cepaL.) and its Role in Crop Reproductive Success. Pakistan J. Zool., vol. 40(6),2008, 451-456.

[12] Horse fly Wikipedia.. An electronic article at http://en.wikipedia.org/wiki/Horse-fly,2011

[13] B. Tolon and Y, Duman.. The effect of pollination by honeybee (Apismellifera) on onion (Allimcepa) seed production and quality. XXXVIII ApimondiaIneternational Apicultural Congres, 2003, 554.

[14] Chandel R.S,. Thakur R.K, Bhardwaj, N.R., and N. Pathania, Onion seed crop pollination: a missing dimension in mountain horticulture. ActaHorticulturae, 631, 2004, 79-86.

[15] Currah, L. and D. J. Ockendon, Onion pollination by blowflies and honeybees in large cages. Annals of Applied Biology, Vol. 103(31), 983, 497-506.

[16] Jablonski B, Skowronek J,Woyke H.W and R. W. Doruchowski,Biologiakwitnienia, nektarowanie,zapylanie i owocowaniemêskosterylnychliniicebuli (AllimcepaL.). Pszczel. Zesz. Nauk. 26,1982, 57-104.

[17] Wójtowski F., Z. Wilkaniec and B. Szymaoe, Hymenoptera,Dipterazapylaj ${ }^{1}$ ce cebule (AllimcepaL.) W poznañskichgospodarstwachnasiennych. Rocz. AR w Pozn. 120, 1980, 161-168.

[18] IH,Willians, Insect Pollination and Crop Production: A European Perspective . InKevan P \& Imperatriz Fonseca VL (eds) Pollinating Bees - The Conservation Link Between Agriculture and Nature - Ministry of Environment / Brasília, 2002, 59-65.

[19] Rao, G.M. and M.C.Suryanarayana, Effect of honeybee pollination on seed yield in onion (Allium cepaL.). Indian Bee J., 51,1989, $9-11$.

[20] Ahmed M.M, Rahim, M.A and M.A. Khan, Effect of planting time and plant spacing on quality seed production of onion (cv. BARI piaz-2). J. Bangladesh Soc. Agric. Sci. Technol. 4 (1\&2), 2009, 161-164.

[21] Mondal, M.S. and A. Hossain,. Effect of time of planting of onion bulbs on the yield and quality of seeds. Bangladesh J. Agric. 5 (3),1980, 131-137. 